\title{
The pedagogy of Jesus in the parable of the Good Samaritan: A diacognitive analysis
}

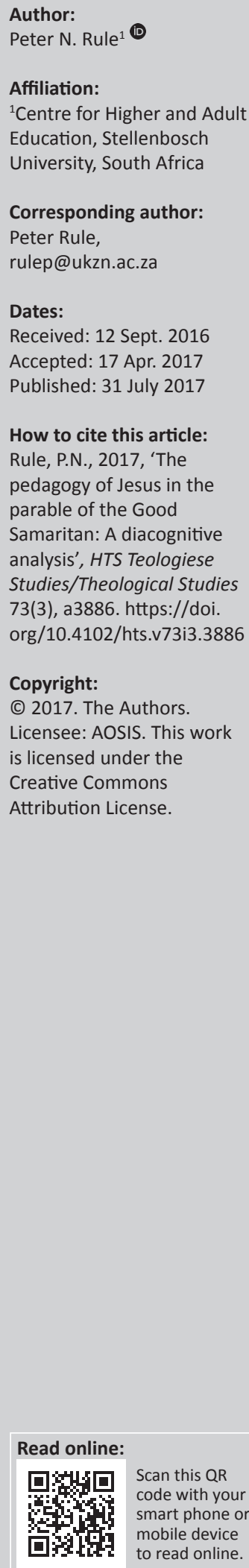

\begin{abstract}
Jesus of Nazareth, like Socrates, left nothing behind written by himself. Yet, the records of his teaching indicate a rich interest in dialogic pedagogy, reflected in his use of the parable, primarily an oral genre, as a dialogic provocation. Working at the interface of pedagogy, theology and philosophy, this article explores the parable of the Good Samaritan from the perspective of dialogic pedagogy. It employs an analytical approach termed diacognition, developed from the notions of dialogue, position and cognition, to analyse the moves within the parable and the teaching situation in which it is located. The article explores how Jesus engages the dialogue of and around the parable to position and reposition his interlocutor, provoking a re-cognition of what it means to love one's neighbour. It concludes by reflecting on the implications of this analysis for the relation of meaning to knowing and doing.
\end{abstract}

\section{Introduction}

The question of the nature, form and purpose of Jesus' pedagogy of parables has been widely debated. Kvernbekk (2012) has characterised Jesus' teaching through parables as monologic, citing the parable of the Sower as an example of 'one-to-many' communication. Herzog (1994) used a Freirean lens to understand Jesus' parables as subversive 'codifications' that challenge the political and economic status quo, and Jesus as a 'pedagogue of the oppressed' (see Scheffler 1991). Others have characterised his pedagogy as paradoxical (Freeman 2010), critical (Newell 2009), constructivist (Robertson 2008), unorthodox (Richardson 2002) and concerned with the transformation of enculturated consciousness (Spear 2005) and conventional morality (Burbules 2004). Although there are many interpretations of the specific qualities and contribution of Jesus' pedagogy, and even of its effectiveness (Dillon 1995), there is general agreement that teaching was a central aspect of his ministry and had a striking impact, not only on his disciples but on Western culture and beyond for the 2000 years since he lived and taught.

Jesus wrote nothing that we know of, except a cryptic signing on the ground when the Pharisees brought before him a woman caught in adultery (Jn 8:1-11). It is likely that he spoke Aramaic as his primary language as a Jewish native of Galilee but also knew and used Hebrew and Greek (Fassberg 2012; Ong 2016; Tresham 2009). The records of what he said and did were created by others mainly in Greek, drawing on an existing oral lore (Funk, Scott \& Butts 1988). The written tradition of Jesus' words and acts preserved only a few of the Aramaic words that were attributed to Jesus. This means that any discussion of Jesus' life and teaching is filtered through a number of recontextualisations: from an oral Aramaic tradition (possibly with other vernacular elements) to a written Greek tradition which only began 40-70 years after his death; from the Jewish cultural setting of Jesus' times to an early Christian culture of the church that codified his life in writing; and through the subsequent accretion of layers of interpretation and redaction through the centuries (Fredriksen 1999; MacCulloch 2010). Acknowledging these limitations of distance and perspective, one of the Aramaic words that survives in the gospels is rabbi, teacher, indicating that this was a primary role attributed to Jesus. With this in mind, it is interesting to explore Jesus' pedagogy and the relatively neglected aspect of dialogue within that pedagogy.

\section{Jesus as teacher}

'Teacher' or 'rabbi' is a recurring identity ascribed to Jesus in the gospels. It was the term of address used most often by others to address him, but also as a self-designation - a total of 59 times in the gospels (Stein 1994). The expert in the law calls him 'Teacher' at the beginning of the parable of the Good Samaritan that I examine below. Borg (2011) sees Jesus as a particular kind of teacher, not a conveyor of information or knowledge, nor even a moral teacher giving information on right or wrong. Rather, he sees Jesus as a teacher of wisdom, which he understands as a 'genre of teaching' with typical forms (short sayings, stories) and typical content (What is the character of God? What 
is real/valuable? How shall we live?) (Borg 2011:166). Borg sees these questions as related: 'wisdom teachers teach a way of life (how shall we live?) grounded in a perception of reality (what is real? What is the character of God?)'.

Borg (2011:166) distinguishes between two kinds of wisdom teachers: those who teach conventional wisdom, the wisdom of a culture (a body of directives and guidance grounded in the experience of generations) which finds its typical expression in the proverb; and those who challenge the cultural consensus of conventional wisdom. The teaching of conventional wisdom through the use of proverbs and folk tales has a strong resonance in African oral traditions, as reflected in the work of writers such as Chinua Achebe (1958) and Ngugi wa Thiong'o (1965). For Borg, Jesus falls into the second category: 'Jesus taught a counterwisdom because of his experience of God'. Spear views Jesus' teaching of a counterwisdom as directed towards the transformation of the encultured consciousness of his listeners (Spear 2005), and this found expression particularly in his use of parables.

\section{Jesus and parables}

Jesus' use of parables is central to his pedagogy, as reflected in Mark's gospel: 'He did not say anything to them without using a parable' (Mk 4:34). Jeremias (1972) argues that Jesus was the first to use this form within the Rabbinic tradition. This is not to say that parables did not already exist in the literature of the ancient world. Indeed, the Old Testament includes a number, and passages from the Old Testament might have influenced parables in the New Testament, for example 2 Chronicles 28:15 and the Good Samaritan (Scheffler 2013). Rather, it is the particular way that Jesus used parables as a pedagogical strategy that stands out. One might say that it was his original contribution to ancient Jewish pedagogy. As Snodgrass (2008:1) puts it, 'At no point are the vitality, relevance, and usefulness of the teaching of Jesus so clear as in his parables' - bearing in mind that the parables in the gospels are already interpretations and recontextualisations of an oral tradition. A testimony to their compelling and enduring influence is how many of the parables have become idiomatic in the English language: sowing the seed, a good Samaritan, a prodigal son and so on.

The Hebrew word 'mashal' meant not only 'parable' in the modern sense but also a range of wisdom genres, from maxims to riddles and fables (Vermes 2003). The English word 'parable' comes from the Greek word parabole: 'from the preposition para, "alongside of," and ballein, "cast, place or throw"' (Donahue 1988:5). This suggests that central to speaking in parables is making comparisons. In the Bible, the parable literary form includes comparisons not only in narratives but also in proverbs, wisdom sayings and allegories. Dodd (1961), a renowned British scholar of Jesus' parables, defines the parable as follows:

At its simplest the parable is a metaphor or simile drawn from nature or common life, arresting the hearers by its vividness or strangeness, and leaving the mind in sufficient doubt about its precise application to tease it into active thought. (p. 16)
Dodd's definition points to the pedagogical purpose of parables: to tease the minds of listeners into active thought. The purpose thus differs from more straightforward instructional genres such as commandments, rules and procedures. It involves provoking a playful but serious labour of interpretation, an opening to possibilities of meaning, rather than indicating a single denotation.

Features of a number of Jesus' parables thus include the following:

- An originally oral form (arresting the hearers): the parable is told by a speaker to listeners in a particular context of verbal interaction; it has features of oral narrative such as 'a tight, lean compressed style' (Funk et al. 1988:17), pairs of characters (good guy-bad guy, e.g. rich man and Lazarus) and sets of three events; and concrete vivid images. Such features make Jesus' parables memorable and so repeatable and are part of the reason why they have come down to us today.

- A word picture or short story drawing on imagery and characters familiar to listeners: 'drawn from nature or common life' (sowing, harvesting, coins, family and household relationships); as such, the parable draws on 'a picture or situation that is typical of what everyone knows and takes for granted' (Funk et al. 1988:16) - what Donahue refers to as the 'realism' of the parables (Donahue 1988:12).

- Having two levels of meaning: Literal and figurative - 'a metaphor or simile' which operates 'by way of implicit or explicit transfer signals' (Zimmermann 2015:137).

- Challenging listeners and readers to interpret the parable or work out its figurative meaning (tease into active thought): Thus, the parable has no conclusion; it is essentially open-ended and inviting of the hearer's engagement. Paul Ricoeur (1975) sees a pattern in the parables of orientation, disorientation, reorientation as readers lose and find their way in the meaning-making process. This 'disorientation' might comprise a challenge to conventional wisdom (Borg 2011) and a shock, what Reinstorf terms 'the juxtaposition of dissimilarities, the diaphor' (Reinstorf 2013:2), which induces a new vision of world and new possibilities (Perrin 1976).

The parable of the Good Samaritan (Lk 10:25-37), like the parables of the Lost Coin (Lk 15:8-10) and the Unforgiving Servant (Mt 18:21-35), is embedded in a communicative event. It is framed within Jesus' conversation with an expert in the Jewish law. The gospel thus provides a pedagogical context of question-answer in which to understand the parable as a teaching-learning episode. Presumably, many of Jesus' parables arose in similar situations of engagement with particular interlocutors, but their distillation from oral to written, from Aramaic into Greek, many decades later, excises the context of situation and leaves us with the parable as a written text rather than an interactive event. The Good Samaritan, with its context of situation, thus offers the opportunity for exploration using the framework of diacognition set out below. 


\section{Diacognition: An analytical framework}

Diacognition is a conceptual framework for understanding and analysing teaching and learning events (Rule 2015). It draws on Paulo Freire's insight that teaching and learning are moments in a wider process of knowing (Freire 2004). This framework consists of three overlaying lenses which provide distinctive but complementary perspectives on the way that a particular teaching and learning episode relates to processes of coming to know. These are dialogue, cognition and position. They are best presented as components of a triangle that can be 'folded in' to overlay a teaching-learning event, providing a mutually informing and enriching cumulative perspective.

I briefly describe each of these components in turn (see Figure 1).

\section{Dialogue}

My understanding of dialogue as both an ontological feature of human existence and an encompassing facet of human communication draws on the work of Buber (1937), Freire (1972; 2000), Bakhtin (1981; 1984) (see Rule 2006; 2011), Hermans (2013) and Hermans and Hermans-Kanopka (2010). An ontological perspective views dialogue as central to human being: to be human means to be in dialogue - with others, with oneself and with the world. As Bakhtin (1984:287) puts it, 'The very meaning of man (both internal and external) is the deepest communion. To be means to communicate'.

As an analytical lens, dialogue focuses on the nature of the engagement among and within persons in the teachinglearning situation, as well as among non-personal elements. It includes dimensions of the interpersonal (between persons), the intrapersonal (within persons) and the transpersonal (between elements that include but lie beyond immediate personal experiences). Interpersonal dialogue includes interactions between teacher and learners, and

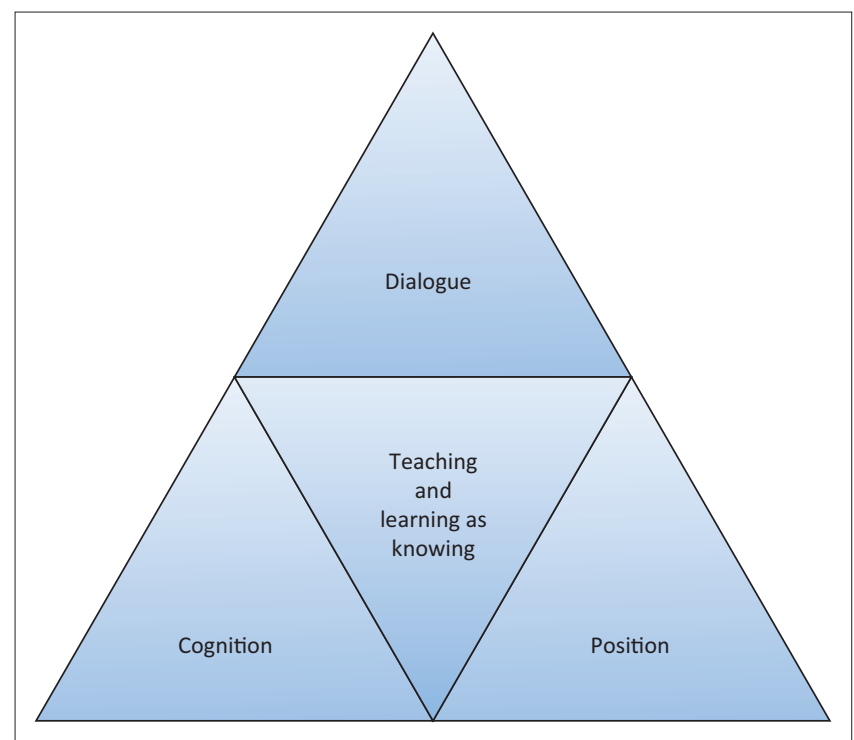

FIGURE 1: Diacognition. among learners. Intrapersonal dialogue takes place within participants as 'talking to self' and might be reflected in writing, speaking, body language or other symbolic codes. This internal dialogue might derive from an interpersonal dialogue as the self continues to dialogue with the other-inthe-self: 'What did my teacher mean by X? Perhaps it means Y. No, maybe ...'. The transpersonal includes interactions between texts, genres, situations, ideologies, times and places, and would both inform and be informed by the interpersonal and intrapersonal. For example, a dialogue between teacher and learners might simultaneously be a transpersonal curricular dialogue between the current lesson and summative assessment: 'Is this for exams?' 'No'. 'Then why do we have to learn it?'... Specific interpersonal and intrapersonal dialogues thus often instantiate and inform dialogues among wider issues at a transpersonal level.

\section{Cognition}

Cognition focuses on the processes involved in coming-toknow, rather than on knowledge as a corpus or object. Following Freire (2004), it assumes that a teacher, who already knows something (an object of cognition), seeks to lead learners to a cognition of this object through a teaching-learning process. In doing so, the teacher recognises the object (knows it again) as a teacher and for the learners and their learning: an algebra teacher has to think about how best to help learners to come to know an equation. She recognises it from the learners' point of view, 'experiencing the other side', to use Buber's term, and so cognising the learners, before crossing back to her own side as the one who instigates learning and 'inclusive education' (Buber 1964). Similarly, the learners 'learn' the teacher (She's got a funny way of doing things!) as well as the particular topic, and the relation between the two.

Teaching-learning includes moments of intercognition, in which teacher and learners share a cognition of the object or aspects of it (the 'Aha!' moments that teachers treasure), and of metacognition, in which they reflect on their own processes of teaching, learning and knowing (Last time I did it this way and it worked for me. So let me try it again.). Decognition is the realisation that you do not know what you thought you knew, as is often characteristic of Socrates' interlocutors in Plato's dialogues (I thought I knew but now I'm really lost!). The 'object of cognition' might be anything to be known - a skill, a concept, a procedure, a set of relations, a perspective, a story or parable and so on. Cognition always involves a subject or subjects (knowers) focusing on an object to be known and is therefore intentional. Cognition might be instantaneous, akin to a flash of light, or take some time, even a life time, to reach its full realisation. In addition, cognition is always situated in a particular context which frames and informs the meaning-making process.

\section{Position}

'Position' is a powerful analytical tool partly because of its range of denotations and its metaphorical import. It includes a spatial sense of someone being in or seeing from a particular 
location (the desk in the corner), the social sense of being placed in society (race, gender, profession, age) and the attitudinal (disenchanted, optimistic) and ideological (Marxist, Liberal, Anarchist) senses. In addition, it can refer to particular 'place holders' available to participants in discourse: a teacher in classroom discourse may adopt positions towards learners such as I-as-questioner, explainer, facilitator or devil's advocate, but not legitimately as lover, corporal punisher or propagandist - which might be legitimate in other discourses.

Teaching and learning as knowing involve participants who adopt particular 'self-positions' (Harre 2002; 2004; Hermans \& Hermans-Kanopka 2010) which are more temporary and flexible than 'roles' (teacher, learner, assessor, examination candidate, activist). They involve doing expressed in external and/or internal actions in particular situations (e.g. I-as-listener, questioner or explainer) and also emotions and attitudes (e.g. I-ascurious, sceptical or enthusiastic). These self-positions might change continuously as participants reposition in a teaching-learning event or might remain relatively stable. The descriptive lexicon regarding positioning includes position (adopt stance for oneself and/or impose stance on other[s]); reposition (take up or impose new position); proposition (propose particular content to others); disposition (respond to a proposition by rejecting, modifying or presenting an alternative); composition (develop a collective position with others). Positioning might therefore be understood as the repertoire of moves within a teaching-learning event pertaining both to the self and others. It is also informed by participants' positionality, understood as the wider social location of participants, including class, race, language, age, sexual orientation, professional status and so on.

The framework of diacognition assumes that the components of dialogue, position and cognition are mutually informing. For example, what and how one thinks is shaped by the kinds of dialogue that one engages in and the positions that one adopts within these dialogues. In the words of a Cat Stevens song, 'From the moment I could talk I was ordered to listen'. The recurrent positioning of a child in any dialogue as the one who must listen would strongly circumscribe cognition. On the contrary, cognition dynamically informs decisions regarding how to participate and position oneself in dialogue: 'I don't understand what you are saying. Please give an example'. The interactions among dialogue, cognition and position are always situated within contexts of discourse and power: in an authoritarian educational setting, a learner may not feel she can request the teacher to explain or give an example, because the positions of 'I-as-questioner' or 'I-as-not understanding' are not available.

I now move on to a diacognitive analysis of the parable event, presented in Box 1 for ease of reference.
BOX 1: Luke 10:25-37; New International Version.

On one occasion an expert in the law stood up to test Jesus. 'Teacher', he asked, 'what must I do to inherit eternal life?'

'What is written in the Law?' he replied. 'How do you read it?'

He answered: "'Love the Lord your God with all your heart and with all your sou and with all your strength and with all your mind"; and, "Love your neighbour as yourself"'.' 'You have answered correctly', Jesus replied. 'Do this and you will live'.

But he wanted to justify himself, so he asked Jesus, 'And who is my neighbour?'

In reply Jesus said, 'A man was going down from Jerusalem to Jericho, when he fell into the hands of robbers. They stripped him of his clothes, beat him and went away, leaving him half dead. A priest happened to be going down the same road, and when he saw the man, he passed on the other side. So too, a Levite, when he came to the place and saw him, passed by on the other side. But a Samaritan, as he travelled, came where the man was; and when he saw him, he took pity on him. He went to him and bandaged his wounds, pouring on oil and wine. Then he put the man on his own donkey, took him to an inn and took care of him. The next day he took out two silver coins and gave them to the innkeeper. "Look after him," he said, "and when I return I will reimburse you for any extra expense you may have"'.

'Which of these three do you think was a neighbour to the man who fell into the hands of robbers?'

The expert in the law replied, 'The one who had mercy on him'. Jesus told him, 'Go and do likewise'.

\section{The Good Samaritan: A diacognitive analysis}

Dialogue

The parable is dialogic at a number of levels. At an interpersonal level, it emerges from, and is embedded in, a dialogue between Jesus and the expert in the law (EL). It takes the form of a set of alternating rejoinders of questionanswer. EL asks his first question, 'What must I do to inherit eternal life?' Jesus answers with a question, 'What is written in the Law?' EL answers the question: Love God and love your neighbour. Jesus endorses the answer. The dialogue appears to have come to an abrupt halt, ending in apparent consensus - Nikulin (2010:78) calls consensus 'the termination of dialogue' - as Jesus' moves show that EL's question was not an authentic quest to know in the first place. EL then asks a second question, 'And who is my neighbour?' Jesus tells a parable as a response. He then asks EL a question about the parable, relating it to EL's second question: 'Which of these three do you think was a neighbour ...?' EL answers, 'The one who had mercy on him'. Jesus concludes with an instruction, 'Go and do likewise'.

Jesus does not give the answers but rather calls on EL to answer his own questions: first, by drawing on his own knowledge of the Law; second, by interpreting the parable and using it to answer his second question. Jesus, seen as 'Teacher' by EL, uses a dialogic form to provoke EL into thought and to challenge him to come to his own conclusions. Matusov (2011) sees as one strategy of dialogical pedagogy a teacher-developed 'dialogic provocation'. Such a provocation would engage learners ontologically with something that excites and/or interests them - Jesus' use of the parable resonates here (see also Zimmermann 2008).

Intrapersonal dialogue is indicated explicitly in two places: firstly, 'an expert in the law stood up to test Jesus' (Lk 10:25). This indicates that EL must have engaged in an internal dialogue along the lines of: 'How can I test this man? I know, I'll ask him ...'. Secondly, the phrase: 'But he wanted to justify 
himself' (Lk 10: 29) suggests an internal conversation such as, 'He has shown me that I already knew the answer. How can I save face? I'll ask him "who is my neighbour?"' Implicitly, the dialogue indicates that each interlocutor internalises the other and formulates a response accordingly. For example, on hearing the EL's first question, Jesus might have had an internal dialogue along the following lines: 'Why is he asking me that? An expert in the law knows the answer. He must be testing me. I'll turn the question around on him'. We will explore below how the analytical lens of 'position' further illuminates these moves.

At a transpersonal level, dialogue works in multiple ways, three of which I discuss here. Firstly, there is a dialogue between genres: the commandment (Love your neighbour) and the parable (the Good Samaritan). The questioning of the commandment (Who is my neighbour?) instigates the parable and the parable exemplifies the commandment. However, they are very different kinds of genres with different forms and purposes. Secondly, whereas a commandment takes the form of the imperative and tells the reader or listener what he or she is required to do, the parable takes a declarative and implicitly interrogative form, creating a narrative which concretely situates the abstract commandment and provokes the reader or listener to make an interpretation. Thirdly, wheareas the commandment is semantically closed and elicits the response: obey or disobey, the parable as a form of narrative is semantically open and works through a metaphor requiring personal interpretation: Which of these three do you think was a neighbour to the man? It requires that the reader or listener becomes an active participant in the meaning-making process rather than a passive recipient of instruction.

At a related intratextual level, there is a dialogue between and among the responses of the three characters who pass the half-dead man. The priest and the Levite pass by, possibly because, as commentators have pointed out, according to Jewish law, they were not allowed to defile themselves by touching a corpse (Vermes 2003). In contrast, the Samaritan shows compassion, meticulous attention and responsibility. The 'arresting strangeness' of this was that Samaritans were considered heretical outcasts in Jewish society and not to be associated with. The idea of a Samaritan being a 'neighbour' to a Jew would have been profoundly shocking to the Jewish audience, particularly in the light of the inaction of the exemplary figures of the priest and the Levite. The intratextual dialogue among the responses to the half-dead man thus links to a dialogue between the parable and the socioreligious context of the audience.

Finally, it is a dialogue between knowing and doing, or cognising something and putting it into practice. EL's question, 'What must I do to inherit eternal life?' indicates that he wants to know what to do. Jesus' answer also indicates a relation between the two: 'What is written in the Law? How do you read it?' Knowing the Law arises from or comprises a practice of reading or interpreting it. EL answers, indicating that he knows what the Law requires. Interestingly, Jesus does not stop with an endorsement of his answer: 'You have answered correctly' - in other words, you know the answer. This is not sufficient: 'Do this and you will live'. A similar kind of knowing or doing dialogue arises within and around the parable that Jesus then tells. I return to this aspect under 'Cognition' below.

\section{Position}

The positionalities of the participants centrally inform their positioning within and around the parable. Jesus as an adult Jewish male, an itinerant healer and teacher, speaks with surprising authority, although he does not appear to have any formal scholarly training. EL is also an adult Jewish male, but represents the religious establishment, and his authority comes from this standing. Jesus encountered a number of such representatives - Pharisees, Sadducees, scribes - who engaged him with a variety of motives: curiosity, suspicion, outrage; some receptive to his message; others intent on catching him out.

Figure 2 indicates the positioning of Jesus and EL in the telling of the parable, both their adopted positions and the positions that they ascribe (in brackets) to their interlocutor. The arrows indicate the addressor-addressee flow of the dialogue.

Positioning involves taking up positions in discourse and simultaneously positioning others. Thus, EL takes up the position of questioner and positions Jesus (Teacher) as the one who knows and has authority to pronounce on the topic. Implicit in the question is thus a proposition about his interlocutor: You are a teacher who can answer. Jesus chooses not to accept this imposed position. Rather, he repositions himself by answering with a question. As was characteristic of Socrates, here he prefers to ask the question and so allow his interlocutor to make the running. EL accepts this positioning and proposes an answer: Love God and love your neighbour. Thus, he makes a proposition about how to inherit eternal life and about himself: I am one who knows 'what is written in the Law' and 'how to read it' and am able to pronounce on this. This proposition contradicts his earlier position as questioner and reveals that the question was not an authentic quest for knowledge about inheriting eternal life, but rather a test of Jesus. Jesus positions himself as an assessor of the proposition's validity, thus effectively reversing the positions of assessor and assessee: 'You have answered correctly. Do this and you will live'. Here he positions EL as one who knows (knower) and one who can act to realise his knowledge in practice (agent).

EL then repositions himself as a questioner: 'And who is my neighbour?' - once again positioning Jesus as an authority. Jesus accepts this positioning, but obliquely, and answers with a parable. He thus moves away from the formal language of the Law and the commandments, and into the language of narrative. This move positions EL and the audience as listeners to a story, requiring a different kind of receptiveness. As they listen, they are participants 


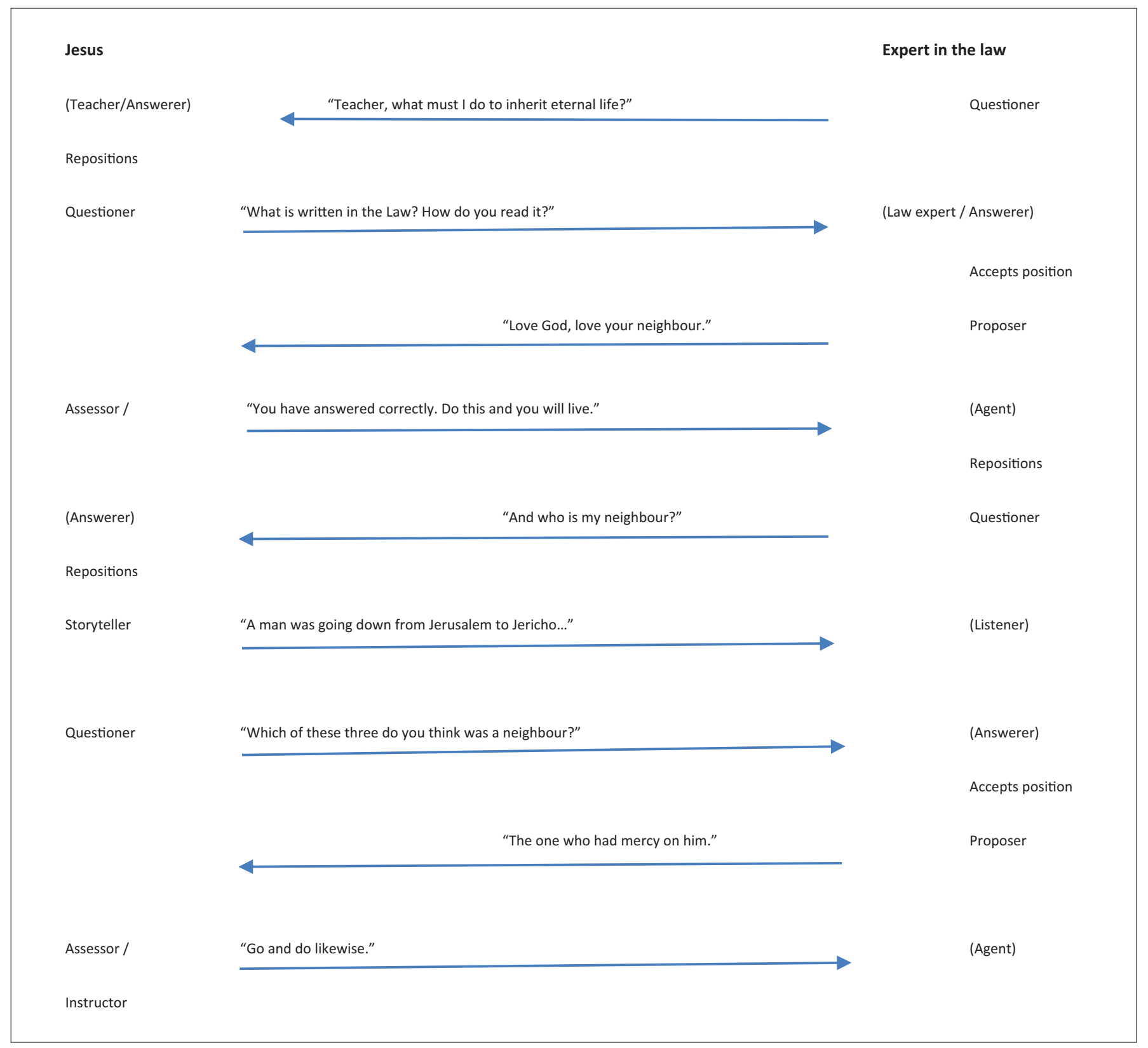

FIGURE 2: Positioning in the parable of the Good Samaritan.

in and makers of meaning: they interpret the story at a literal and figurative level. 'What will happen to the poor robbed man?' they might think as they listen. 'And what has this got to do with loving your neighbour? Who is the neighbour in this story?' They nod knowingly when the man is robbed: They have heard stories about that road. They exchange surprised looks when the priest and the Levite pass by. They hear with foreboding of the appearance of a despised Samaritan: Will he finish the injured man off?

At the conclusion of the parable, Jesus adopts the position of questioner and positions EL to answer. EL accepts and proposes that 'The one who showed him mercy' was a neighbour to the robbed man. Implicitly endorsing EL's proposition, Jesus instructs him to do likewise, thus again positioning him as a knower and an agent.

\section{Cognition}

The initial object of cognition, introduced by EL's question, is what must be done to inherit eternal life. EL re-cognises this in his answer to Jesus' question - cognises again what he already knows: Love God and love your neighbour. Jesus' response indicates that he also knows this. Because both Jesus and EL already know the answer, there is no new object of cognition. What cognition, then, arises from their dialogue? Jesus cognises the motive of EL: to test him. EL realises this; he knows that Jesus knows: There is thus an intercognition between them of what his motive is. This leads him to recognise his motive from Jesus' point of view and, presumably, to experience a 'temporary self-position' (Hermans' understanding of emotions) of some discomfort and perhaps embarrassment. He develops a strategy to 'justify himself' and save face by coming up with an authentic question. 
This introduces a new object of cognition: Who is my neighbour? Jesus, perhaps realising that this is a genuine question, does not ask EL to answer. Instead, he tells the parable. However, after telling the parable, he changes the object of cognition from 'Who is my neighbour?' to 'Which of these three do you think was a neighbour to the robbed man?' He thus shifts attention from the robbed man, the victim, to the one who helped him, the agent; from the expected object of cognition whom you should love as a neighbour to who loves as a neighbour.

The parable and the question that follows it are a shocking inversion which turns the expectations of the audience upside down. They position the audience to identify, and identify with, the despised outsider. It is the Samaritan, 'a deplorable character in 1st century Palestine' (Reinstorf 2013:2), not the priest or the Levite, who is an exemplar of love. This must have been acutely uncomfortable, if not offensive, for members of the audience: Not 'love your enemy' but 'my enemy loves me; I should be like him'. It calls upon them to question their own assumptions about status and positionality, indicating that not who you are but your willingness to be touched on the inside, literally in the entrails, by the sufferings of others (Zimmerman 2008) and how you act in response that is crucial in loving your neighbour.

The parable and Jesus' pedagogical framing of it also point to a particular relation between knowing and doing, cognition and action. It is not enough for EL and the audience to have solved the puzzle of the parable: to have cognised the one who loves his neighbour. This is only the first step which leads nowhere unless it is followed by another: 'Go and do likewise'. 'Likewise' points to the metaphorical import of the parable. It means understanding and enacting the learning from the parable in the complexity of everyday life. As with the Samaritan, this might involve risks and costs. Jesus' injunction invites a living and unfolding dialogue between parable and praxis.

In this sense, the re-cognition of the parable in lived praxis begins where the parable ends. The parable opens out into the possibilities of an enactment of loving one's neighbour which cannot be prescribed but only lived. It requires that participants actively 'read' life and respond to it as they have listened and responded to the parable: likewise. This fortuitous English term, indicating an amalgam of 'like' and 'wise', suggests a certain practical wisdom or phronesis in contextual application: to do 'likewise' (emulate the Samaritan) and to be 'like-wise' (discern when, whom and how it is appropriate to love as one's neighbour, with all the complexities involved). Perhaps this is at the heart of the metaphorical cognition involved in the lived praxis that Jesus' parable, as a dialogic provocation, invites as a response.

\section{Conclusion}

This article presented diacognition, including the components of dialogue, position and cognition, as an analytical framework for understanding teaching and learning as knowing. It offered a reading of the Good Samaritan as a pedagogical episode using this framework. What emerges from the multifocal perspective of diacognition is Jesus' use of the parable as a 'dialogic provocation' within a dialogic pedagogy. Jesus' positioning and repositioning of himself and his interlocutor enable a learning dialogue that includes not only the formal cognition of the commandment to love your neighbour, but the metaphorical cognition of a parable about what this means. In particular, it explores the critical relation in the Good Samaritan between parable and praxis, the reciprocity of knowing and doing, and the ethical challenge of doing 'likewise' and being 'like-wise'. Although Jesus never, to our knowledge, formulated educational outcomes, lesson plans or assessment rubrics, his pedagogy of parables continues to provoke, challenge and even upend our assumptions about 'the other' in human conduct, and to question what it means to teach and learn dialogically.

\section{Acknowledgements}

\section{Competing interests}

The author declares that he has no financial or personal relationships which may have inappropriately influenced him in writing this article.

\section{References}

Achebe, C., 1958, Things fall apart, Heinemann, London.

Bakhtin, M.M., 1981, The dialogic imagination, University of Texas Press, Austin, TX.

Bakhtin, M.M., 1984, Problems of Dostoevsky's poetics, University of Minnesota Press, Minneapolis, MN.

Borg, M., 2011, Jesus: Uncovering the life. Teachings, and relevance of a religious revolutionary, Society for Promoting Christian Knowledge, London.

Buber, M., 1937, I and Thou, T. \& T. Clark, Edinburgh.

Buber, M., 1964, Between man and man, Collins, London.

Burbules, N., 2004, 'Jesus as teacher', in H. Alexander (ed.), Spirituality and ethics in education: Philosophical, theological and radical perspectives, pp. 7-20, Sussex Academic Press, Brighton.

Dillon, J.T., 1995, Jesus as teacher: A multidisciplinary case study, International Scholars Publications, Bethesda, MD.

Dodd, C.H., 1961, The parables of the kingdom, Charles Scribner's Sons, New York.

Donahue, J.R., 1988, The gospel in parable: Metaphor, narrative, and theology in the synoptic gospels, Fortress Press, Minneapolis, MN.

Fassberg, S.E., 2012, 'Which Semitic language did Jesus and other contemporary Jews speak?', The Catholic Biblical Quarterly 74, 263-280.

Fredriksen, P., 1999, Jesus of Nazareth King of the Jews: A Jewish Life and the Emergence of Christianity, Macmillan, London.

Freeman, C., 2010, Post-metaphysics and the paradoxical teachings of Jesus: The structure of the real, Peter Lang, New York.

Freire, P., 1972, Pedagogy of the oppressed, Penguin, London.

Freire, P., 2000, Pedagogy of the heart, Continuum, New York.

Freire, P., 2004, Pedagogy of indignation, Paradigm, Boulder, CO.

Funk, R.W., Scott, B.B. \& Butts, J.R., 1988, The parables of Jesus: Red letter edition. The Jesus seminar, Polebridge, Sonoma, $C A$.

Harre, R., 2002, Cognitive science: A philosophical introduction, Sage, London.

Harre, R., 2004, 'Positioning theory', viewed 1 August 2016, from http://www.massey. ac.nz

Hermans, H., 2013, 'The dialogical self in education: Introduction', Journal of Constructivist Psychology 26(2), 81-89. https://doi.org/10.1080/10720537.2013. 759018

Hermans, H. \& Hermans-Kanopka, A., 2010, Dialogical self theory: Positioning and counter-positioning in a globalizing society, Cambridge University Press, Cambridge.

Herzog, W., 1994, Parables as subversive speech: Jesus as pedagogue of the oppressed, Westminster/John Knox, Louisville, KY.

Jeremias, J., 1972, The parables of Jesus, SCM Press, London. 
Kvernbekk, T., 2012, 'Revisiting dialogues and monologues', Educational Philosophy and Theory 44(9), 966-978. https://doi.org/10.1111/j.1469-5812.2010.00695.x

MacCulloch, D., 2010, A history of Christianity, Penguin, London.

Matusov, E., 2011, 'Authorial teaching and learning', in E.J. White \& M.A. Peters (eds.), Bakhtinian pedagogy: Opportunities and challenges for research, policy and practice in education across the globe, pp. 21-36, Peter Lang, New York.

Newell, T., 2009, 'Worldviews in collision: Jesus as critical educator', Journal of Education \& Christian Belief 13(2), 141-154. https://doi.org/10.1177/ 205699710901300206

Ngugi wa Thiong'o, 1965, The river between, Heinemann, London.

Nikulin, D., 2010, Dialectic and dialogue, Stanford University Press, Stanford, CA.

Ong, H.T., 2016, The multilingual Jesus and the sociolinguistic world of the New Testament, Koninklijke Brill, Leiden.

Perrin, N., 1976, The kingdom of God in the teaching of Jesus, Fortress Press, Minneapolis, MN.

Reinstorf, D.H., 2013, 'The parable of the shrewd manager (Lk 16:1-8): A biography of Jesus and a lesson on mercy', HTS Teologiese Studies/Theological Studies 69(1), Art. \#1943, 1-7. https://doi.org/10.4102/hts.v69i1.1943

Richardson, M.O., 2002, 'Jesus: The unorthodox teacher', in P.H. Peterson, G.L. Hatch \& L.D. Card (eds.), Jesus Christ: Son of God, Savior, pp. 225-247, Religious Studies Center, Brigham Young University, Provo, UT.

Ricoeur, P., 1975, 'Biblical Hermeneutics', Semeia 4, 27-138.

Robertson, W.H., 2008, 'The greatest constructivist educator ever: The pedagogy of Jesus Christ in the Gospel of Matthew in the context of the 5Es', Christian Perspectives in Education 1(2), 1-17, viewed 3 February 2015, from http:// digitalcommons.liberty.edu/cpe/vol1/iss $2 / 5$
Rule, P., 2006, 'Bakhtin and the poetics of pedagogy: A dialogic approach', Journal of Education 40, 79-102.

Rule, P., 2011, 'Bakhtin and Freire: Dialogue, dialectic and boundary learning' Educational Philosophy and Theory 43(9), 924-942. https://doi.org/10.1111/ j.1469-5812.2009.00606.x

Rule, P., 2015, Dialogue and boundary learning, Sense, Rotterdam.

Scheffler, E., 1991, 'Reading Luke from the perspective of liberation theology', in P.J. Hartin \& J.H. Petzer (eds.), Text and interpretation: New approaches in the criticism of the New Testament, pp. 281-298, Brill, Leiden.

Scheffler, E., 2013, 'The assaulted (man) on the Jerusalem - Jericho road: Luke's creative interpretation of 2 Chronicles 28:15', HTS Teologiese Studies/Theological Studies 69(1), Art. \#2010, 1-8. https://doi.org/10.4102/hts.v69i1.2010

Snodgrass, K.R., 2008, Stories with intent: A comprehensive guide to the parables of Jesus, Eerdmans, Grand Rapids, MI.

Spear, S., 2005, 'The Transformation of encultured consciousness in the teachings of Jesus', Journal of Transformative Education 3(4), 354-373. https://doi. org/10.1177/1541344605278009

Stein, R.H., 1994, The method and message of Jesus' teaching, Westminster/John Knox, Louisville, KY.

Tresham, A., 2009, 'The languages spoken by Jesus', The Master's Seminary Journa 20(1), 71-94.

Vermes, G., 2003, The authentic gospel of Jesus, Allen Lane, London.

Zimmermann, R., 2008, 'The etho-poietic of the parable of the good Samaritan (Lk $10: 25-37$ ). The ethics of seeing in a culture of looking the other way', Verbum Et Ecclesia JRG 29(1), 269-292. https://doi.org/10.4102/ve.v29i1.16

Zimmermann, R., 2015, Puzzling the parables of Jesus: Methods and interpretation, Fortress, Minneapolis, MN. 